\title{
岡山招魂社創建と「公園」の空間変容 MODIFICATION OF DESIGN ON THE PARKS IN OKAYAMA WITH BUILDING OF SHOKON-SHA SHRINE
}

\author{
小野芳朗*
}

\section{Yoshiro ONO}

\begin{abstract}
After the Meiji-era, the forest around Shin-to shrine was refined as Shin-en (The forest for God) in order to keep shrine's authority. This Shin-en had also function as the Urban Park. This paper discusses an example of building of a shrine and a park in Okayama City. The Shokon-sha shrine (the Shin-to shrine dedicated the sprits of war dead soldiers) was built in 1869 on a hill Higashi-yama where the shrine dedicated Tokugawa Shogun from 1644 that was the most important memorial space for the governor Daimyo Ikeda. After the stationing of Army 17 division in 1907, the Shokon-sha shrine was rebuilt with the refined Shin-en Parks designed by the technocrat belong to Ministry of Imperial House as the authority for the sprit of soldiers of Imperial Army.
\end{abstract}

Keywords : Okayama, City Planning, Shokon-sha Shrine, Act by Dajo-kan, Koraku-en garden 岡山, 都市計画, 招魂社, 太政官布達, 後楽園

\section{1. 緒論}

明治以降、神社を軸とする公園が数多く創られた。それは単に神 社の歴史や、公園の歴史としてみるのではなく、神社という装置を 使った都市空間創出の契機であったと考えるのが本論の主題であ る。

神社の創建と公園の関係については以下の研究事例がある。明治 6 年の太政官布達正院第 16 号による府県への公園設置は広く知ら れているところではある (以降「太政官公園」と略記)。それは神 社や寺院の境内地を指定することが多かった。東京の市区改正にお いては、公園設置の目的に「衛生」の要素があったとしても、実際 には計画の大半を神社境内地が占めたことを野崎は指摘している ${ }^{1)}$ そして東京府からの公園への財政支出は、公園化によって神社境内 地を保存し、国家神道の祭祀という社会的地位の一方で、上地によ

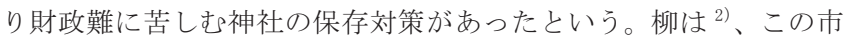
区改正には「風致的資質」は見出せず、創建神社の境域に風致を求 めることが展開されてきたとし、岡山招魂社の地に太政官公園が開 設された例や、熊本八代宮附属地公園の例をあげる。また旧都市計 画法第 10 条第 2 項の「風致又八風紀ノ維持ノ為」の条項の具現が 橿原神宮の県立畧傍公園や明治神宮内苑 - 外苑、伏見桃山陵や武蔵 多摩陵の周囲にあるとするが、都市計画法の実施の適用との関連に ついては実証していない。

公園を国家の象徵的空間として演出された例に、小野は ${ }^{3)}$ 東京上
野公園をあげる。幕藩時代に京都に倣い江戸鎮護の山として東㕡山 に宽永寺と徳川家霊廟が置かれていた。そこに明治天皇が明治 9 年 の上野公園開園時に訪れ、また高台から東京を眺める「国見」をし た。上野公園は天皇の「可視化装置」の機能を果たしたという。ま た神社地を公園とするのは、そこが人民輻輳の地であるということ のみならず、「天皇制の清浄な空間」として整備されていたことを 高木は指摘する ${ }^{4)}$ 。岩倉具視の主張により、荒廃していた京都御苑 は明治 11 年より 3 年かけて整備され、石垣で囲まれた平安京大内 裏をイメージする御苑ができあがる。それはやがて明治 19 年から の伊勢神宮に始まる近代の「神苑」の形成につながり、その延長に 橿原神宮、熱田神宮、明治神宮の神苑造園があり、そして札幌神社、 村々の神社へと全国に広がっていくという。中嶋は 5)、京都の神社 の「神苑」創出の社会的背景として(1)上地による境内の荒廃回復、 (2)神社としての尊厳の創造、(3)参扯者のための施設の充実をあげる。 神社を中心とした国民の教化、統制、ナショナリズムに基づく郷土 風景の保全、都市公園としての存在価值の高揚など市民と神社をつ なぐ装置としての「神苑」が創出されたという。

神社が旧城郭の中に置かれ公園化する例も多い。大阪城本丸につ いて能川は ${ }^{6)}$ 、陸軍第四師団との相関を指摘する。大正 12 年 7 月 から 9 月にかけて大阪市協和聯合会（池上四郎市長が会長）が仁徳 天皇を祭神とする浪速神宮の造営計画をもちだす。本丸内にあった 師団司令部敷地の譲渡を求めるが、師団側の建物新築移転の条件に

\footnotetext{
* 京都工芸瀻維大学大学院建築造形学部門 教授・工博 $\quad$ Prof., Dept. of Architecture and Design, Kyoto Institute of Technology, Dr. Eng.
} 
計画は頓挫する。その同じ構図が昭和 6 年の昭和御大典を記念して 作られた大阪城天守閣を軸とする大阪城公園建設時にも軍の新築 要求がでてくる。神社と公園の問題は、近世の地方支配の象徵であ る城郭空間に及んだ時に、近代の陸軍駐留との相関性が浮き出てく る。近世の歴史性を強調する例もある。羽賀は ${ }^{7}$ 、犬山城本丸が明 治に稲置公園となり、元白山社である針綱神社が城内に移転され、 犬山の歴史的集約の場として創出される事や、領主成瀬氏の霊と戊 辰戦争戦攻者の霊を祀る犬山神社が明治 16 年に創建され、その集 約が高まっていくことを記している。

こうした戦歿者慰霊の招魂社の創建は仙台においても城郭内に なされる。佐藤は ${ }^{8)}$ 仙台における招魂祭が藩祖伊達政宗にちなむ青 葉神社祭礼と合体し、軍官民合同の招魂祭となり、やがて明治 35 年仙台城本丸内の昭忠標の建設と、同 37 年の招魂社の創建につな がっていくという。招魂社の立地は慰霊の地にできるケースが多く、 東京招魂社は大村益次郎が明治 2 年九段坂の上に設置し、京都は平 安京以来の東山の霊地・霊山にでき、大阪鎮台招魂社は当初真田山 陸軍墓地に併設される。金沢では本康が ${ }^{9}$ 、层霊空間と表現するよ うに「場所性」や地域民衆の「精神性」を求める立地がなされる。 兼六園から望む卯辰山は前田家の所縁の観音院や八幡宮のある祭 祀空間であった。そこに明治 3 年卯辰山招魂社ができる。また明治 13 年には兼六園内に前田家が天皇家の藩屏たる象徵として日本武 尊を模った明治紀念標が建立される。そして招魂祭は明治 20 年よ り兼六園（兼六公園）内で執行された。

植民地における神社創建は帝国日本の象徴としてより直裁的に 現出する。姜は ${ }^{10)}$ 朝鮮における創建神社である仁川神社（1890） と仁川・東公園、大邱神社（1906） と達城公園、ソウルの南山大神 宮（1898）と南山公園、釜山の龍頭山神社（1898）と龍頭山公園の 例をあげ、日本人居留地に創建神社を建て、その境内外に公園を造 出し、日本風の環境を創出していったと指摘する。明治 43 年の韓 国併合後、田村剛によって南山公園が調查され、それを境域の風致 の一部とする朝鮮神宮が大正 14 年に鎮座する。青井は台湾神社の 創建が植民地都市形成の契機となったことを述べる。当初、「公園」 だから、という理由で圓山に造営される予定の台湾神社は、総督児 玉源太郎により高台で台北市外を見渡せる剣潭の地にできる ${ }^{11)}$ 。ま たその昭和 14 年の拡張は内苑・外苑の機能や施設のヒエラルキー に応じた計画的区分であったことを指摘している ${ }^{12)}$ 。

こうした神社と関連しあって現出する公園あるいは神苑の設計 者が存在する。朝鮮神宫神苑は東大の本多静六とその弟子田村剛で あった。京都における神社の「神苑」設計には、松尾大社を野間守 人京都府技師（のち名古屋市の公園事業に携わる）、伏見稲荷大社 は寺崎良策であった ${ }^{5)}$ 。彼は明治神宮造営局技師を務めた人物で、 京都府立植物園も設計する。こうした専門的技術を有する技師たち はまた宮内省内苑寮に集中していたことが示唆されている。なかで も著名なのは、新宿御苑を学術研究の場として利用した福羽逸人や 出雲大社神苑などを設計した市川之雄、明治神宮造営局技手でのち に内匠寮庭園課長の中島卯三郎などがいる ${ }^{13)}$ 。こうした技師たちの 教育の場として新宿御苑が使われたという ${ }^{14)}$ 。

佐藤昌はその著で ${ }^{15)}$ 、福羽の系列に市川や折下吉延、林旅、椎原 兵市、そして明治神宮内外苑の設計をした原熙をあげている。しか しながら宮内省内苑寮の技師たちの実態についてはその全容を知
るものは現在のところ研究がない。

本論で対象とする岡山市は近世には外様雄藩池田家三十一万五 千石の城下町であった。明治になって日本三大名園のひとつに数え られる後楽園を大名庭園として有していた。明治 40 年に陸軍第 17 師団設置が決まり、軍の常駐する軍都の性格も有する事となった。 後楽園は明治以降も池田家の所有が続き、明治 17 年岡山県への有 償譲渡後も県会の開催や陸軍大演習など様々に利用され、やがて大 正 11 年名勝指定により歴史的文化財への道を歩むことになる。岡 山県は「太政官公園」としては後楽園ではなく東山と呼ばれる場を 「偕楽園」として指定した。そこは近世には池田藩にとって徳川の 家臣松平家であることを象徴する東照宮の鎮座する空間であり、明 治以後旧藩主が藩知事として執行した招魂祭が招魂社社殿となっ て形を現し、それゆえに太政官公園に指定され、その後護国神社と して今日まで慰霊空間として継続している。この空間の公園として の機能は、時代の画期を反映して様々な企図で設計されていく。都 市空間の形成を担う一端に公園があり、それが歴史的記憶を積層さ せる形で神社空間を重ねていく過程と、その契機になっていく陸軍 師団の設置をあわせてみていく。

使用した資料は「岡山市東山公園設計平面図」などが京都工芸繊 維大学美術工芸資料館で発見され、それを基礎とし、それらを裏付 けていく形で岡山市側の公園選定と招魂社移築に関する資料を集 めた。公園設置と招魂社移築は岡山市の事業である。しかしその当 時の市会議事録は存在せず、市会の議事を抜粋要約した『岡山市会 史』昭和 61 年刊も多くを山陽新報の市会記事に依拠しているため、 本論では主としてこれら双方を採用しながら論を進める。

\section{2.太政官公園と慰霊空間}

\section{2-1 東山慰霊空間}

近世における城下町岡山の都市形成を担った主体は藩主池田家 である。鳥取藩から岡山に転封される池田光政の時代（寛永 9 年 (1632) から寛文 12 年 (1672) まで藩主) に城下は整備され城下西部 まで武家屋敷が建設され、次代綱政の時（正徳 4 年(1714)まで）に 旭川の洪水防除のためのバイパス・百間川が貞享 4 年 (1687) 開鳌さ れ、これにより城下東部、旭川左岸の東山地域（門田屋敷）に武家 屋敷が新たに建設されるとともに、御後園（後楽園）が建設された (元禄 2 年使用開始)。そして幕末から維新期、廃藩置県とともに 旧藩主章政は旧藩士とともに岡山都市形成に少なからず関与して いく。

著者は岡山城下から旭川を隔てた東側の山陽街道沿いの東山地 域が近世に池田家の慰霊空間であったと共に、明治になり池田家が 天皇家の藩屏池田公爵家となる事を、この東山の地に空間的に表現 していったことを明らかにした ${ }^{16)}$ 。本節で概観して本論の準備と成 す。

東山地域は岡山東部の操山連山の端にあたる。中世より幣立山南 頂にある玉井宮の北の頂に正保元年 (1644)、当時の藩主池田光政 が全国に先駆けて東照宮を勧請した。その社僧の住む利光院と愛宕 宮が山麓にあった。光政の正妻勝姫が天樹院千姫の娘であったこと により、池田家は徳川家の姻戚松平伊予守左近衛権少将家として江 戸時代の家格を継いだ。明治維新直前、岡山藩は藩内を尊王攘夷派 が主導し、藩主に水戸徳川斉昭の九男茂政を迎えた。茂政は十五代 
将軍慶喜の実弟であったために鳥羽伏見の開戦にあたり藩は茂政 を引退させた。代わって藩主に迎えられるのが藩祖光政の血統であ る腩政で、朝廷側に立ち維新を迎えた。

章政は操山山頂に明治元年三勲神社を創建し、備前出身の朝廷を 援けた人物、和気清麻呂、児島高徳、これに自身の先祖と称する楠 木正行を祀る。徳川家由来の東照宮に替わり、朝臣としての池田家 を象徵する建築物を建てた。明治元年に祠を建て、同七年に東照宮 宮司の佐々木亀次郎らの名で教部省に申請している注 1)。

當縣下第六区操山偕楽園之地二於テ和氣穈卿楠正行児島高徳之社宇造営之 義昨七年二月中奉願同三月中許可二相成今般右社宇建営仕候付社号之義 三勲神社卜相称申度候間何卒至急御 潟被置下度此相奉願候也 明治八年一月 佐々木亀次郎 野崎武吉郎、和氣辰包

図 1 に明治期の東山地域の図を示す。

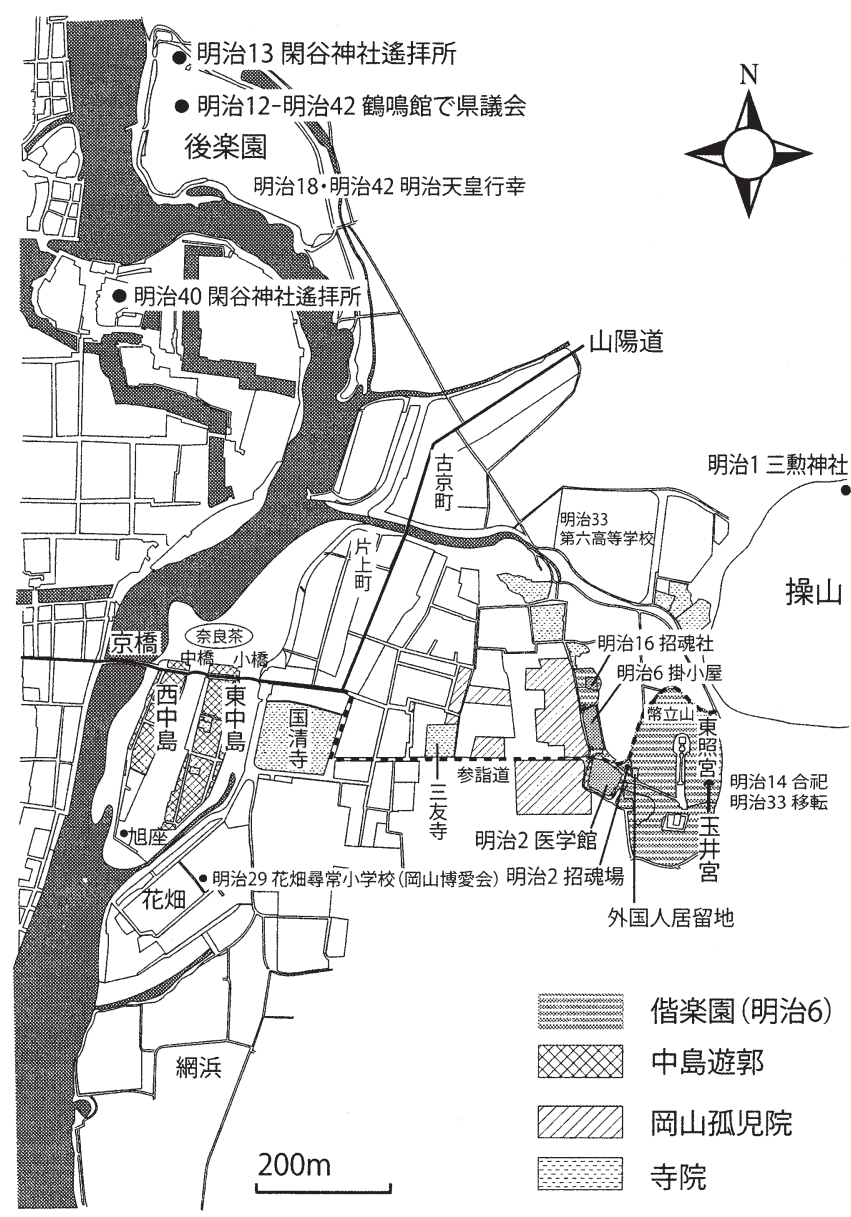

図 1 岡山市東山地区の近代における諸施設（年号は成立年）

一方で東照宮は郷社に落とされ一応存続してはいたが、明治 14 年 宮司佐々木玄孫は氏子と合議の上、玉井宮に合祀し、東照宮鎮座の 北頂へ玉井宮が遷座した。この明治 14 年段階での合祀は東照宮の 氏子組織に土族が多く賛同が得られやすかったと『玉井宮東照宮 誌』は説明している注 2)。空間的にも東山（地域名は門田屋敷）に 石井十次の岡山孤児院注 ${ }^{3)}$ ができるなど武家屋敷は消えていくが、 実際にはどれくらいの士族がこの地域に残存していたのだろうか。 東照宮に部分的に保存されている明治 30 年前後と推察される氏子
名簿注 ${ }^{4)}$ には以下の表 1 のような平民と士族の世帯数が数えられる。

表 1 東山地域の世帯数（東照宮氏子名簿より）

\begin{tabular}{|l|l|l|}
\hline 世帯数 & 平民 & 土族 \\
\hline 花畑一 & 140 & 24 \\
\hline 古京町 & 174 & 18 \\
\hline 小橋町 & 232 & 62 \\
\hline 東中島町 & 251 & 13 \\
\hline 網浜 & 319 & 52 \\
\hline 阴田屋敷 & 377 & 152 \\
\hline
\end{tabular}

この表から東照宮の鎮座した幣立山山麓の門田屋敷や小橋町、網 浜など旧武家町にはなお多くの土族の世帯があり、とくに門田屋敷 では世帯の約半数を士族が占めていたことがわかる。『玉井宮東照 宮誌』のいうように東照宮合祀に氏子の意思が働き、その多くに土 族の意識が入っていたとするのは資料的に限界があるが、山麓地域 に存在した士族が比較的多かったことは確かめられた。

\section{2-2 太政官公園・偕楽園と池田家の後楽園}

全国に公園の設置を求められた太政官布達正院第 16 号により、 岡山県は東山界隈を公園・偕楽園に指定した注5)。

當管内御野郡岡山城東操山ノ義、池田家ノ時、東照宮习祭祀シ、士民恽楽遊 觀ノ場所ニシテ、從前高外除地二屬セル分二御座候、其景況北二熊岦、龍口

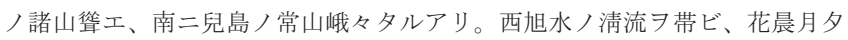
此境ニ遊ブ者、心ヨ嬉シクシ、意ヨ慰ムルノミナラズ、熊获、常山ヨ望ミタ ル忠臣烈士ノ跡 7 想像シ、自然欣慕ノ感 7 興スニ依り、池田家其ノ麓二於テ、 戊辰ノ役、奥羽戦歿ノ士卒 7 祭祀シ、招魂ノ所卜爲セリ。今般御達二依リ、 永ク萬人偕楽, 公園卜被相定度、則地所巨細取調圖面相添一奉伺候也。

明治六年三月十七日 岡山縣權参事 石部誠中 岡山縣權令 新庄厚信 （指令）書面操山之儀、從前高外除地二候上八、申立之通リ、自今公園地二 相定候條、後來境界紛亂無之様取締方見込相立、實測繪圖相添尚可申出事

$$
\text { 明治元年三月三十一日 租税頭 陸奥宗光 }
$$

以上の申請書にみるように岡山・偕楽園は高外除地（免税地）で 名勝地であり、三勲神社の神体や招魂社があるからだという。東山 の地は太政官布達に沿った地を選択したが、社寺境内地の官有地編 入の太政官の意図の中で、この地が池田家の直轄地であったことが 公園指定の理由になったと考えられる注5)。

この文中にあるように公園指定に先立つ明治 2 年 6 月に利光院跡 地に招魂社が建立される。廃藩置県に伴い官祭になる (県に移管) が、明治 16 年愛宕宮跡地（図 1 参照）に移設される。東照宮は近 世には徳川家の姻戚という政治的シンボルであったし、池田藩の最 も重要な祭礼は隔年 4 月 17 日・9 月 17 日の東照宮祭礼であった。 その城下のシンボルであったエリアが太政官公園となり、その同じ 空間内に池田家の忠臣を顕彰する招魂社が建立された。それは池田 侯爵家への転進とともに官祭となって岡山県出身の国家のための 戦争の兵役戦㱛者を祀る靖国神社の系列へと入っていく。また池田 家の天皇家への接近を宣言した三勲神社は、やがて池田家が皇族と 姻戚となる（明治 23 年章政嫡男詮 政が久爾宮朝彦親王三女安喜子 女王と結婚）とともに尊重され皇室を象徵する空間となる。

一方の御後園（後楽園）は版籍奉還により岡山城を県に明け渡し 
た池田家一族が居住空間として使っていた。ここには廃藩置県で池 田章政が東京に召還されたのちも池田家が所有していた。明治 4 年、 後楽園と名称を変え、一般県民の観覧を許可するものの、日程を男 女別にし、雨天時は中止など限定的な開放にとどまっていた。また 明治 5 年には池田家一族の後楽園鶴鳴館などへの移転により再び閉 園となる。明治 17 年融資焦付き事件により池田家はその弁済のた め後楽園を岡山県に有償譲渡した。これにより管轄が岡山県地方課 となり、明治 23 年に池田家が返還を要求するが県会はこれを受け 入れず、以後今日まで岡山県の所有物となる。

明治 18 年 8 月山陽巡幸の明治天皇が後楽園を訪れ、池田章政が その接遇をした。この事実が報道で取り上げられ、岡山後楽園の名 が全国的になり同様に行幸のあった金沢兼六園と行啓のあった水 戸偕楽園をして「日本三名園」とした、というのが諸説の一致して いるところである注 6)。県に移管後、明治年間を通して後楽園では 鶴鳴館において岡山県会や各種総会が行われ、また明治 21 年より 池田章政の帰岡にあわせ旧藩士の園遊会（のちに温故会）が開催さ れた注 7)。

このように太政官公園・偕楽園に比して後楽園は明治天皇の行幸 という事実以外は一般公開するものの「公園」イメージよりもむし ろ池田家の残像が濃い。岡山で開催されたいくつかの博覧会（明治 12 年岡山民立博覽会、大正 8 年岡山物産共進会）も、後楽園内は会 場とならない。また明治 13 年、当初東山偕楽園内に計画された閑 谷神社遥拝所が曲折の末、後楽園北隅に造営され注 8)、毎年 4 月 18 日を祭日とする。閑谷神社は藩祖池田光政を祀る和気郡木谷村にあ り、遥拝所は池田家とその藩士たちの精神的中心として後楽園に残 る。明治 40 年にそれが岡山城本丸西に遷るが跡地は池田家の所有 として残された。こうした池田家の残像が後楽園から事実上消滅す るのは、茂政明治 32 年、章政明治 36 年、詮政明治 42 年と幕末か ら明治にかけての池田家当主が他界し、岡山からその記憶が薄らい でいく頃、大正 8 年遥帱所跡地も岡山県に移った。

大正期の後楽園と偕楽園（この頃には東山公園の名称となる）を 比較した観光案内記によると、

観光の旅者この公園に入れるも尚ほその公園たるを悟らずして更に東山公

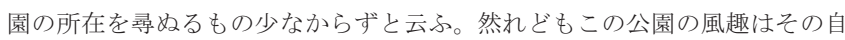
然の秀美を以て勝れるものにして岡山の地人工的光景園としては既に後楽 園あり。注 9)

東山公園あり、一に偕楽園と称し園域甚だ廣く天然の風致を主としたるよ り後楽園の人工美に對して偕楽園は自然の景致を賞すべし注 10)

とある。この東山公園（偕楽園）は自然景観で、後楽園は人工景観 という論調は昭和の観光案内にも引継がれ、

東山公園、一に偕楽園とも云ひ地域高燥、山あり谷あり、松翠概蒼、而かも 展望廣調、人工の美は後楽園に及ばないが天然の風致に優つてみる。注 11)

このように大正 8 年前後には太政官公園から自然公園となってい く東山公園（偕楽園）と、池田家が居なくなった、それ故歴史的庭 園として記憶された人工美後楽園の二極が岡山に公園として存在 していた注 12 )

\section{3. 東山公園の再編 \\ 3-1 陸軍第 17 師団の設置と岡山電気軌道}

岡山市が近代的インフラを整備し、都市が成長してくるのは明治 40 年前後とみてよい。ひとつは全国 8 番目の近代水道が旭川上流の 三野を水源地として明治 38 年開設された。三野は近世岡山の城下 およびその西部の田園地帯に用水を供給していた西川用水幹線の 取水口の直下流にあたる ${ }^{17)}$ 。そこに浄水場が建設され北向背地の半 田山内に配水池が設けられ市内給水がなされた。この岡山市水道を 設計したのは陸軍省技師の吉村長策である。吉村は給水を自然流下 にする事、すなわち配水池を高地に設けてその圧力で配水する事、 そして水源を田戋灌溉用水の水利権を重視し、その直下流の三挺樋 より引水することを決めた注 ${ }^{13)}$

もうひとつは明治 39 年の山陽鉄道の国有化により、その株主た ちが代金を資本として設立する電気鉄道群のひとつであり、神戸資 本（岸本豊太郎ら）と岡山資本（杉山岩三郎ら）が明治 45 年 5 月 5 日に開通する岡山電気軌道である。軌道は城の外濠を埋立て道路を 拡幅した上に敷かれた。その設立主旨の一つに明治 40 年設置の陸 軍第 17 師団の輸送をあげた注 14$)$ 。第 17 師団は津島の田畑を買収し、 用地北東にある既設の半田山配水池から軍用水道を引き込んだ。そ の設置理由のひとつが水道施設にあったことは、「岡山市ニ八既設 ノ水道アリテ各部隊二分用セ八衛生防火上八勿論大二至便ノ義二 付」という書類でわかる注 ${ }^{15)}$ 。

さらに中国鉄道（津山線）の法界院駅を設け、線路を師団に引き 込み人資を輸送した。陸軍の設置は水道インフラや、鉄道の国有化、 それによって派生した市内電気鉄道の開設とリンクしている。電気 軌道の電源は水力電気の創設による。都市郊外にダムを作り、水力 電気は当初岡山市営が検討されるが、明治 39 年京都帝国大学土木 工学科の大井清一や田辺朔郎により調查が始められ、明治 41 年に 水利使用許可願書がだされた ${ }^{12}$ 。

このように水力電気、道路拡幅を伴う市街電車と水道敷設など都 市インフラの基本が整備され近代都市としての体裁を整えてくる ようになった明治 40 年代に第 17 師団の設営がなされた。

\section{3-2 東山公園拡張設計}

後楽園は人工的景美、東山公園は自然的景観の棲み分けが観光案 内には記されたが、一方で後楽園は陸軍特別大演習の大本営の性格 も有し、東山公園内には戦歿兵士の霊を祀る招魂社が存在した。

都市インフラの整備と陸軍師団設置は、公園の形態に変容をもた らす。後楽園が師団設置後の明治 43 年に陸軍特別大演習の大本営 として園内の元藩主の御座所延養亭を天皇の行在所とした。明治天 皇は明治 18 年の山陽巡幸に次いで来岡する。のち昭和 5 年にも昭 和天皇が再び陸軍特別大演習の大本営に選ばれる。さて一方の東山 公園は拡張案が浮上寸る。その理由は公園内の招魂神社境内が陸軍 師団兵士の参拝には手狭である、との理由であった。

明治 40 年に招魂社神職佐々木玄棌注 17) と有志総代名で岡山県知 事宛に願書がだされる注 18$)$

官祭招魂社移転敷地下附願

岡山市字門田幣立山所在

官有地第三種東山公園面積拾壱町七反六畧壱歩八内面積壱千六百坪 當県岡山市大字門田字幣立山鎮座官祭招魂社八戊辰已已東征二殉難シタル 
當県下出身五十五名/霊魂 7 官費祭祀相成、且ツ丁丑西南及明治二十七八年、 三十三年并三十七八年戦役二従事/戦病死者中一千九百二十名ノ霊魂 $モ モ$ 私費合祀ノ所二有之、然ル二漸次合祀者増加スルニ従七遺族ノ数モ亦夥多卜 為リ現境内 $コ$ 以毎年執行ノ例祭八勿論如上ノ遺族ヨシテ参拝セシメ難キ 状態二相成無己今回有志者相謀リ前記ノ地 7 譲受ケ移転致度候間無代価 以于御下附被成下度別紙神社明細帳写図面移転工事設計書相添此段相願候 也。明治四十年 月 日（月日の控えを欠く）

官祭招魂社受持神職 佐々木玄孫

同有志総代香川真一注 ${ }^{19)}$ 谷川達海 中西厚道

明治 40 年時点では移転理由は現境内が狭いが、その移転先の希 望は同じ岡山県の所有する（管理は岡山市）幣立山の東山公園内と している。この東山公園移転案は神社側が旧境内に隣接した土地を 求めたが、そこも狭いとの理由で許可がおりていない。偕楽園（東 山公園）は文中にあるように官有地第三種の太政官公園であり、一 方後楽園は第二種指定の県庁附属地であった。

師団設置後の東山における招魂祭の状況が報道されている注 20)。 祝砲と花火があがり例大祭が始まる。師範学校、工業高校など各種 学校の生徒の参扯は午前 7 時より順次済ませ、正午頃になると市民 が押しかけ、午後 1 時頃には「大道筋には群集の為め歩行容易なら ず近年視ざる雑沓たりし」とあり祭典の参加者は二千余人、その他 一般参扯者は万を数えた。余興に角力撃剣等あり「附近は非常なる 雑沓を極めたり」とある。こうした敷地の手狭さを指摘する報道が ある注 21)。この頃になって東山公園内ではなく、その東方の操山裏 手の奥市に新たに敷地を求める案が浮上してくる。奥市へ移転し拡 張することによって遊園地（東山公園）も拡張されれば、「一方各 師団各部隊の将卒が一時に参拝することありとするも別に差支も 生せさべし」とある。

この時「調查委員会」十名がその委員長である岡田磐市長ととも に東山に赴き調查した。東山公園の東方、奥市は操山山麓に位置し、 岡山市内から見ると右手から東照宮のある幣立山、そして操山とそ れに続く東山連山が続くが、奥市は操山の裏にあたる。奥市への移 転・拡張案はその後市会で具体化されていくようである。明治 43 年 3 月 29 日の市会において、東山公園の設備の件、奥市に市の公 園を設備する件が承認される注 22$)$ 。明治 45 年 2 月には「来る五月の 招魂祭に関し十七師団幹部の意向として」、津島の師団練兵場にお ける招魂社建設案を全廃し、東山官祭招魂社において挙行する事を 決めたことが報じられた。また明年度予算の「公園拡張費六十餘圓」 が通過したことも報じられた注23)。この 60 円は誤報であり『岡山市 会史』の明治 45 年 2 月 26 日によれば注 24$)$ 、東山公園拡張費四千円 について大幅な減額案が提出されたが否決、原案通り執行となって いる。

陸軍は東山招魂社敷地の手狭さを問題にしていた。そこで練兵場 内に招魂社建設を目論むが、2 箇所の招魂社は無用の経費と便宜の 悪さがあるとの県市当局者の立場にも鑑み断念に至る。これは東山 から奥市への移転・拡張を促し予算化された。

東山公園拡張設計とは招魂社の移転・拡大とその跡地利用であっ た。「東山公園設備委員会」は大正 2 年度中に奥市公園を整備し、 次年度に招魂社を誘致し、周辺に桜楓樹を植え付ける事を決めてい る注 25)。この時期に至って岡山市側より招魂社側へ奥市誘致の照会 をだしている注26)。
照会大正二年一月九日

岡山市長 岡田 磐

官祭招魂社神官 佐々木玄孫殿

市内東山官祭招魂社境内并之二接続スル東山公園八其地域何レモ狭盆ナル ガ為メ祭典挙行に際シ其不便実二云フベカラザルモノアルニ依リ、有志間二 於テ移転又八拡張 唱導スルコト久シト雖モ未夕機運此二至ラス、折柄本市 八字奥市二約式町歩ノ公園 新設シ且ツ該社 此地二移転シ、永遠二遺族并 軍隊其他ノ参帱又八余興施設等二遺憾ナキヨ期セントスルノ目的 フ以テ、現 二着々工事進行中有之候条、旁以テ貴職二在リテモ此趣旨二賛同ノ上、速二 移転ノ手続等 $\ni$ 取計相成候様希望二不堪、就テ八至急何分ノ意見承リ度此段 及御照会候

3 日後の 1 月 12 日、佐々木玄孫が岡田市長宛に「社殿ノ改築且境内 ノ模様設計等先決ノ必要性有之」としながらも承諾の旨を提出して いる。

ここで社殿の移転案が岡山市側より招魂社維持会に提出され経 費一万円が計上される注 27)。また玉井宮より三勲神社、奥市に至る 道路（三間ないし四間）の改修による連絡道の予算が委員会で検討 され、委員のひとり菱川吉衛注 28) が千円の寄付を申し出る注 29)。一 方の東山公園の土地所有は招魂社が官祭として置かれた時、明治 4 年から岡山県であった。しかしその管理は岡山市に委託されていた。 この管理権の永久付与を市側が県内務部長に求め、県が応諾し、こ れによって岡山市の東山公園改修についても推進される注 30$)$ 。また 奥市への招魂社移転については一部国有林払下を求めることとな った注 31 。ここの国有林払下については市より大阪大林区署へ通達し た結果、当初 21 町の希望を 11 町に減じて許可されたのが大正 4 年 10 月である ${ }^{32}$ 。招魂社維持会は社殿の設計を岡山県技師桑邱茂に 担当させ、桑邱は上京し靖国神社型に則った建築とすることが決め られる注 ${ }^{33)}$ 。この決定は社殿に関する事のみで、その周辺に桜樹、 杉木の植樹などが議論されている注 34$)$ 。社殿の移転改築については 佐々木玄孫之香川真一両名の連署で岡山県知事湯浅倉平宛願書が でており、その理由として「祭典挙行ノ当日八遺族及各学校生徒有 志者等ノ参帱者其数习増加シタルノミナラズ、第十七師団設置以来 軍隊ノ参拝アリテ、其実況昔日ノ比ニアラス。」とあり注 ${ }^{35)}$ 、第 17 師団設置が境内の狭隘さを増し、この移転に至ったと明記している。 その棟札の写しによれば、大正 13 年上棟祭執行で、造営計画者技 師桑邱茂、その他大工棟梁千野佐喜造他五名、その費用一万五千円 を岡山市川崎町住塚本芳五郎の奉納によるとある。本殿は靖国神社 の様式にならい神明造三間社、屋根は桧皮葺、拝殿は入母屋造屋根 桧皮葺であった。招魂社遷座式は大正 4 年 4 月 29 日に執行され、 神官佐々木玄孫の祝詞のもと、県知事代理の理事官が衣冠束帯で手 水の儀を行った。翌 30 日の臨時大祭には陸軍師団代表の衛戎司令 官長谷部輜重兵中佐、岡山県警部長、維持会代表香川真一、市長、 桑邱技師などが列席した。

この社殿周辺の整備（奥市公園）と移転した東山公園の跡地整備 が宮内省内苑寮技師市川之雄に委託される注 ${ }^{36)}$ 。市川は明治 44 年栗 林公園北園や、大正 4 年の大礼記念の京都御苑などの設計の業績が あり、岡山東山公園もその設計はかねてより専門技師に委䄈る意向 が岡山市側にあった注 ${ }^{37)}$ 。市川の調查のための来岡は同年 5 月 26 日であったが、同日に岡山市は明治 43 年陸軍特別大演習の際の明 治天皇行在所に建て増しした「御便殿」（御湯殿、御衣替所）を県 より譲り受け、奥市公園山頂（操山）に移築し、先帝行幸を記念す 


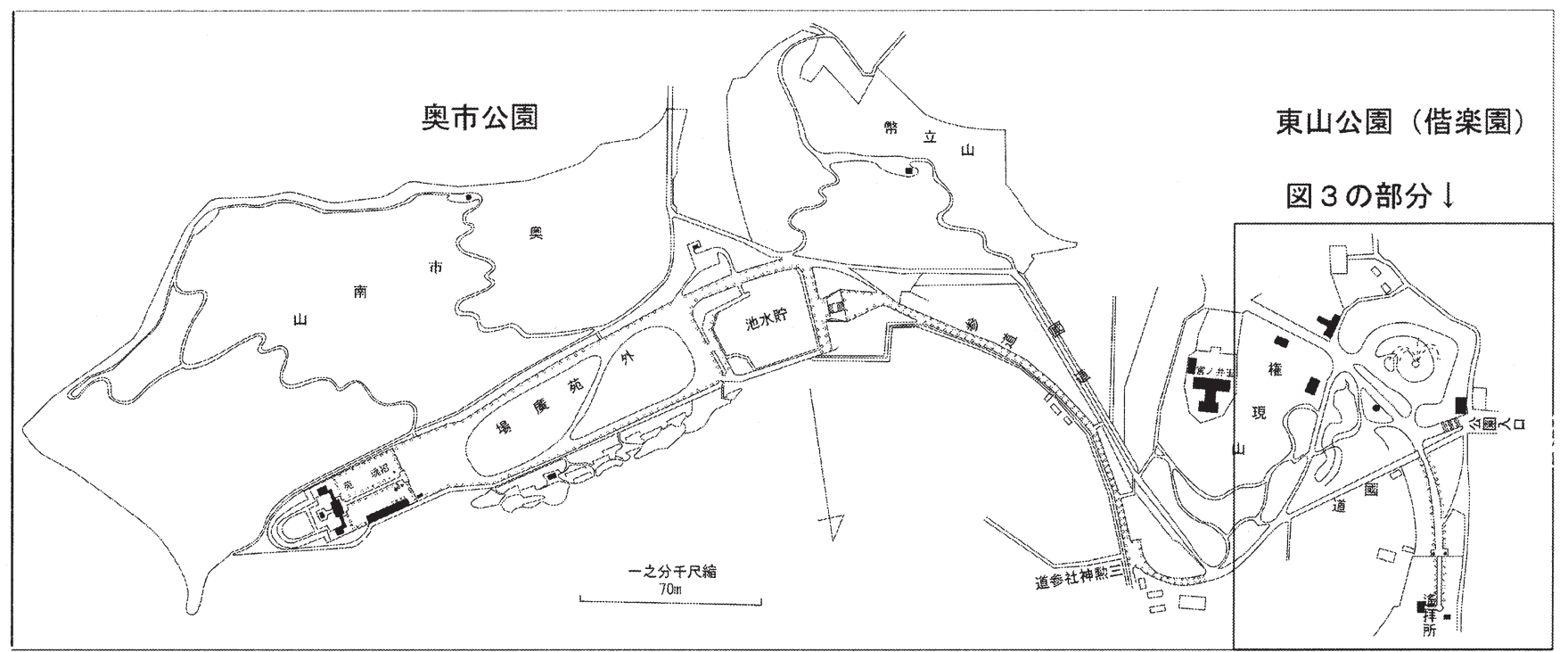

図 2 市川・椎原設計「岡山市東山公園設計平面図」

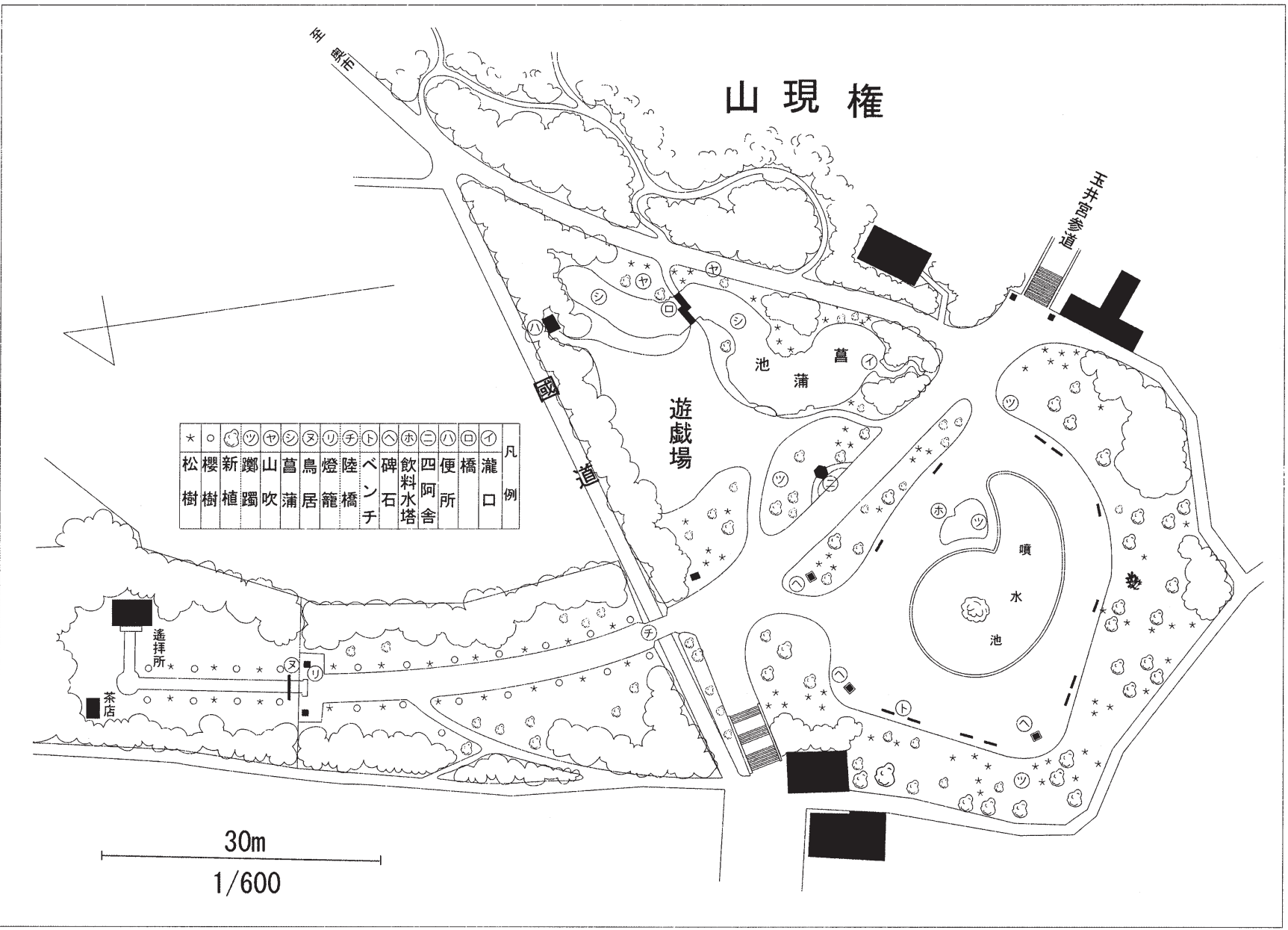

図 3 「偕楽園方面設計解説圖」東山公園設計案

\section{ることを市会で決定する注 38 )}

市川之雄の調查により奥市・東山公園（偕楽園）の基本方針が示 される注39)。その設計部分のみを引用し、要点に下線を施した。

○奥市方面一大グラウンドの新設一

現在招魂社の位置は土地が低けれども今更移轉すること不可能なれば現状
の儘とし杉松等の樹木を植急付け森厳ならしめ之を主景として此方面の設 備を営すにあり招魂社内の周圍は總て公園にて設備し廣場に大グラウンド を設くること、北側に於ける墓地を移轉し其跡に三勲神社に通ずる通路を設 くること、尚階段は設けグラウンドの見物を容易ならしむること、其他に 招魂社参道を新設すること該道路は緩勾配とし貯水池堤防に階段を設け 徒歩参拝者は之に依らしむること、該貯水池は御手洗池と命名すること $\diamond$ 偕楽園附近＝廣場には兒童の遊戯場＝玉井宮を主景として設備するも のにして下手の廣場に貯水池を新設して澈を下し下方の池に注がしむ、舊招 
魂社跡には三勲神社の遙扯所を設置し児童の参拝の便に供ふること、南方の 廣場に兒童の遊戯場を造ること

$\diamond$ 三勲神社附近 同神社を他に移轉せんとの説あるも同神社附近は朓望極 めて佳良なるを以て移轉せしむる必要なし 参道を改造して参扯者の便を 圖ること尚同神社附近は一般遊覽者の展望場として總ての設備を爲すこと

$\diamond$ 奥市南山附近 眺望其他佳ならざるを以て櫻楓樹を植付け下方より眺め 得る様施設すること

○幣立山方面 特徴なき山なれば別に施設する必要なく老人兒童の小高き 遊び場所たらしむべし

$\diamond$ 後楽園連絡道路 後楽園より五百羅漢東山新公園方面に通ずる道路を改 造すること（目下予定線三線に就き実測中）尚東山新公園に通ずる道路を改 造すること（豫定三線あり目下實測中）而して道路の改修墓地移轉は豫算三 萬圓内外なりと云ふ

また東山公園の招魂社跡に三勲神社を移築する案が存在したよ うだが、市川案では三勲神社は現在の位置（操山山頂）が敬神の念 を起しむるとともに一面風致上適当の所なれば、跡地に遥拝所を設 ける案を示した注 40 。ここの公園設計案の図を描いたのが市川の部下 であった椎原兵市である。椎原は明治 40 年京都高等工芸学校図案 科を卒業後、 42 年武田五一の紹介で宮内省内苑寮に入り、先の栗林 公園や京都御苑の設計に参画し、その設計図を描いた。椎原が東 山・奥市公園設計に関わったことは『椎原兵市氏の作品と業績』注 41) 中「公園並遊園地」の項に「大正五年 岡山東公園設計参画」(東 山公園の誤記）とあることで確認できる。また京都工芸繊維大学美 術工芸資料館蔵の椎原作品の一部に「岡山市東山公園設計平面図」、 「偕楽園方面設計解説圖」と題されて保存されている ${ }^{53)}$ 。それを卜 レースして図 $2 、 3$ に示す。

図 2 の奥市公園では招魂社附近は杉松の荘厳な背景のもと、外苑 広場をグラウンドとして改造し、貯水池に階段を設け手洗池となす こととしている。また公園北側より三勲神社の参道を作る。図 3 に 詳述された東山公園は権現山、すなわち玉井宮東照宮の麓に勾玉型 の噴水池を作り、三勲神社遥帱所を旧招魂社跡地に設け参拝路は桜 と松を交植する計画である。児童公園と瀧の落ちる菖蒲池を作る。 そして眺望の良き注 ${ }^{42)}$ 三勲神社へのアクセス道と後楽園への連結道 路を作るというものであった。この公園拡張計画が大正 4 年の大礼 に関与したという記事は見つからない。したがって陸軍師団設置に 伴う招魂社敷地拡大の意図による移転・改修と考えるのが妥当であ る。しかしながら、招魂社、三勲神社、玉井宮東照宮など慰霊空間 の宮内省内苑寮技師の設計主題は天皇家と池田侯爵家、そしてその 臣民たちの慰霊である。近世以来の慰霊空間東山は、明治期に引き 続いて、陸軍により慰霊空間の強化・拡張が行われたとみてよい。

しかし、この市川・椎原案の実現は奥市公園の新招魂社附近の整 備のみで図 3 東山公園は菖蒲池以外は実現していない。実現したの は基本方針中、奥市公園の植樹、グラウンド、手洗池、三勲神社の 参道、東山公園菖蒲池であり、主として新招魂社を中心とする神苑 部のみであった。岡山市会では東山公園内の招魂社跡地と池田家の 後楽園内の閑谷神社遥拝所跡地（遥拝所は明治 40 年岡山城本丸内 一移動）を交換する案が大正 4 年よりおこっている注 ${ }^{43)}$ 。同年 10 月 19 日の市会では旧招魂社敷地についての池田家と県市の交渉が 不調になったことが記されている注44)。記事には書かれていないが、 池田家が交換に応じることで岡山城内にある閑谷神社遥帱所を東

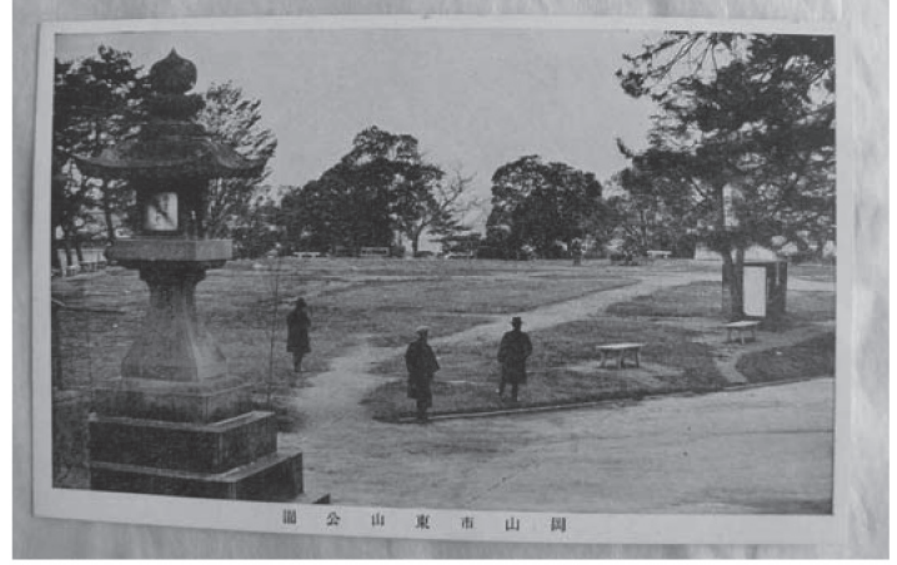

図 4 昭和 3 年ごろの東山公園（東照宮階段下より撮影）

山公園内に移転させることが推測できる。（当初池田家は閑谷神社 遥拝所を東山に、と企図するが玉井宮東照宮に加えて招魂社ができ 百物雑沓のためと、明治 13 年後楽園へ建設した経緯がある)。三勲 神社ではなく閑谷神社を遥拝する。いずれも池田家の祖霊ではある が、これによって後楽園内に残存する池田家の土地を全く手放すこ とに池田家は抵抗し、結局この案も実現しない注 45)。勾玉型の池も 実現した形跡はなく新聞報道より東山公園改修の記事はなくなる。

昭和 3 年、昭和大典記念大日本锥業博覧会の第二会場が東山公園 の入口附近、旧招魂社跡地の下で開催されるが、その時の記念絵葉 書に当時の東山公園の写真（図4）がある注 ${ }^{46}$ )。東照宮の石段より 下を撮影したもので、椎原の図面の勾玉型の噴水池が予定された地 である。実態は芝生の広場として作られたことがわかる。

さて、市川・椎原案は東山公園では実現せず、大正 8 年 4 月に玉 井宮参道と旧招魂社跡地をつなぐ陸橋の南側に現存する直径五間 の円形の噴水池ができる注 ${ }^{47)}$

大正 5 年の東山公園拡張設計によって実現したのは、奥市公園に おける招魂社を中心とする新たな慰霊空間、いわば神苑であり、そ れは桜楓、松杉が植樹され、さらに健康促進を目的としたグラウン ド、遥拝のための手洗池、そして天皇家の藩屏たちを祀る三勲神社 への参道が作られた。それはのちに昭和 14 年岡山県護国神社とし て靖国の空間として機能していく空間の整備であった。

\section{4. 結論}

公園は太政官布達の時より官有地として都市内における公有の 空間として創設された。東山は近世の池田家の直轄地から公有の空 間、偕楽園となった。その後、招魂社の創建により近代の慰霊空間 の性格を現す。都市インフラの整備に伴う市区改正（計画のみ）と 陸軍師団設置の中で公園は「計画」される。それは神社という装置、 英霊の鎮魂（新招魂社）と天皇イメージ（三勲神社）をより強化す る都市空間の創出となる神苑計画であった。それを設計したのは宮 内省内苑寮の技師であった。

一方で後楽園は池田家の所有から岡山県へ移管し、県会や陸軍大 演習などが行われるものの、近世の大名庭園、日本三公園の一、と して歴史的名勝としての地位を築いていく。

このように近世的な空間が近代になり官有の公園地を社寺地や 藩主領の除地に設定し、それが近代の都市空間の創出と連関し、成 
長し変容していく過程は、近世の大名庭園 ・ 東照宮と近代の招魂 社・藩祖の顕彰神社を有する城下町に共通する現象であることも考 えられる。本論では岡山の事例を検証したが他の城下町都市との比 較も検討課題となる。

\section{謝辞}

本論文作成にあたり、岡山県記録資料館、京都工芸繊維大学美術工 芸資料館には資料面でお世話になりました。また資料の収集には岡 山大学大学院環境学研究科大学院生興津洋祐氏の協力をあおぎま した。深甚の謝意を表します。

\section{参考文献}

1) 野崎政和：近代公園の成立過程における国民統合政策の影響, ランドスケ ープ研究, 58 (5), pp25-28, 1995. 5

2) 柳五郎: 風致地区に与えた創建神社の影響, 造園雑誌, 53(5), pp49$54,1990.5$

3) 小野良平: 公園の誕生, 吉川弘文館, 2003

4) 高木弘志:近代天皇制と古都, 岩波書店, 2006

5) 中嶋節子: 近代京都における「神苑」の創出, 日本建築学会計画系論文 集, 493, pp237－243, 1997. 3

6) 能川泰治: 大阪城天守閣復興前史, 大阪の歴史, 73, pp3-116, 2009

7) 羽賀祥二: 城郭公園のなかの神社, 史学 (名古屋大学文学部研究論 集), 42,pp221-241, 1996

8) 佐藤雅也: 近代仙台の慰霊と招魂一戦死者祭祀の変遷一, 調查報告書第 27 号, 仙台市教育委員会, 2009

9) 本康宏史: 軍都の慰霊空間, 吉川弘文館, 2002

10) 姜信龍: 韓国・近代開国期における公園の開設課程とその特質, 造園雑 誌, 57 (1), pp 16-33, 1993.5

11) 青井哲人: 台湾神社の造営と日本統治初期における台北の都市改編, 日本 建築学会計画系論文集, 518,pp237-244, 1999.4

12) 青井哲人: 日本植民地期における台湾神社境内の形成 - 変容過程, 日本建 築学会計画系論文集, 521, pp285-292, 1999.7

13) 鈴木博之監修: 皇室建築 内匠寮の人と作品, 建築画報社, 2005

14) 若泉誠ら: 福羽逸人が園芸・造園界に与えた影響, ランドスケープ研 究, $71(5), p p 469-474,2008.5$

15) 佐藤昌: 日本公園緑地発達史下巻, 都市計画研究所, 1977

16) 小野芳朗: 地方城下町・岡山における景観形成の空間構造に関する研究, 景観・デザイン研究論文集, 7,pp65-74,2009. 12

17）小野芳朗: 水路都市岡山の近世-西川用水前史, 土木史研究論文 集, 28, pp51-58, 2009. 6

\section{注}

注 1）岡山大学附属図書館池田家文庫, 三勲神社創立書類 明治 17 年、YPA-011 注 2）玉井宮東照宮誌、玉井宮東照宮発行、1983

注 3) 石井十次は岡山医学校を卒業後、明治 24 年東山の三友寺を本拠に岡山 孤児院を開設した。基督教会で石井と同じく洗礼を受けた大原孫三郎の支 援を受ける。

注 4) 東照宮氏子名簿、明治 30 年代、岡山玉井宮東照宮蔵

注 5) 岡山市: 岡山市史 第五、昭和十二年、第四章史蹟名勝。明治文献。太 政官布達では「人民輻湊ノ地、古来ノ勝区、群集遊覧、従前高外除地」と あり、申請書に対応している。なお丸山宏『近代日本公園史の研究』思文 閣出版、1994によれば岡山操山（東山）は地目では「藩主東照宮」となっ ており、除地ではあるが池田家の支配下にあり官有地に編入しやすかった と考えられる。

注 6）小澤圭次郎は「明治庭園記」の中で「畢竟日本三名園の題目は一笑を も值せざる俗評」といい、「岡山公園は、元来幽遂の致に乏し園趣なるに天 覧後にて、清掃整潔」と明治 18 年 8 月の天皇行幸が機という。松山市立子 規博物館蔵の子規の後楽園絵葉書の裏に明治 24 年 8 月「日本三公園之一」 とあるのが最初の三公園の記録とされる。

注 7）岡山県郷土文化財団：岡山後楽園史、2001
注 8) 岡山大学附属図書館池田家文庫、閑谷神社遥拝所必要書類、YMC-003 注 9）岡山県内務部: 岡山県名勝誌、大正 4 年、復刻版、1974

注 10）岡山市遊覧案内、1913

注 11) 岡山商工会 : 岡山名勝と名物、1928

注 12）但し、後楽園も設立当初の元禄二年時には岡山上川向こうの田畑を低 い竹垣で囲った地に川の水を堰き止めて池とした自然景観であり、その田 作業をな寸農民の姿を藩主池田綱政が楽しんだ事が自筆歌集（䉛吟集、神 原邦男翻刻、林原美術館紀要・年報、2 号、2007）よりわかっている。田畑 はその後、御後園の財政事情逼迫のため埋められて芝生になった。

注 13) 岡山市水道局: 岡山市水道百年史、2001

注 14）岡山電気軌道株式会社:おかでん七十年のあゆみ、1980

注 15）アジア歴史資料センターref C07041858300、明治 41 年 1 月参大日記、 防衛省防衛研究所

注 16）岡山市役所：岡山市史、1958。大正 2 年中国水力電気会社に売却。

注 17）玉井宮東照宮宮司、三勲神社宮司を兼ねる。佐々木家は池田光政が 東照宮勧請の正保元年に大坂生魂神社の佐々木家から連れてきたとされる。 注 18）岡山県護国神社: 岡山縣護国神社百年史、1976

注 19）旧岡山藩士、明治 12 年大分県令を退き、岡山殖産協会会頭、岡山商 業会議所会頭などを歴任

注 20）山陽新報、明治 41 年 5 月 7 日。

注 21）山陽新報、明治 42 年 3 月 14 日。

注 22）岡山市議会:岡山市会史、第一巻、 1986

注 23）山陽新報、明治 45 年 2 月 7 日。

注 24）岡山市会史 の明治 45 年 2 月 26 日記事。

注 25）山陽新報、大正元年 11 月 14 日。

注 26) 前掲岡山護国神社百年史

注 27）山陽新報、大正 2 年 2 月 18 日。

注 28）常道郡国富村（操山山麓）の名主の家に生れ、大坂の大倉喜右衛門に 師事。維新後県御用達となり、明治 12 年の県庁舎や、官公庁、学校、東山 の外国人居留館の建設を手がけた。山陽鉄道他鉄道工事の請負。岡山市会 議員、岡山電気軌道社長 (岡山県歴史人物辞典、平成 6 年、山陽新聞社) 注 29）山陽新報、大正 2 年 6 月 24 日。 注 30）山陽新報、大正 2 年 7 月 3 日。

注 31）山陽新報、大正 2 年 10 月 2 日。

注 32) 大正 4 年 6 月 19 日第三十三議案 備前国岡山市大字門田字操山森林、 台帳面積二町九反四畧十三歩 五十七町七反五畧十歩の内 - 実測面積 十一町八反六畧一歩、松一万千三百十九本、杉六十七本、雑木二百九本、 江南竹三百二十五本 此代金二千円 理由 門田東山公園拡張に関し市 会の議決を経操山国有林二十一町九反六畧十五歩譲与方出願の処本年六月 三日付岡山小林区署より詮議相成らざるも右出願区域内国有林の一部を売 却すべき旨照会ありしによるもの（岡山市会史より）。

注 33）山陽新報、大正 3 年 2 月 28 日。

注 34）山陽新報、大正 3 年 3 月 2 日。

注 35）前掲 岡山護国神社百年史

注 36）山陽新報、大正 5 年 5 月 7 日。

注 37）山陽新報、大正 2 年 9 月 7 日。

注 38）山陽新報、大正 5 年 5 月 26 日、 5 月 31 日。

注 39）山陽新報、大正 5 年 9 月 5 日。

注 40）山陽新報、大正 5 年 8 月 24 日。

注 41）椎原兵市出版会: 椎原兵市氏の作品と業績、1966

注 42）操山はアカマツ林相であったが、明治期の乱伐により秃山と化し、明 治 34 年「岡山事業区施業按説明書」（国立公文書館蔵）により植林が始ま っていたが、この大正初期は未だ幼木も多く、したがって山頂からの眺望 はよかったと考えられる。

注 43) 岡山市会史、大正 4 年 9 月 15 日。

注 44) 岡山市会史、大正 4 年 10 月 19 日。

注 45）山陽新報、大正 6 年 9 月 29 日。

注 46）「大日本勧業博覧会絵葉書」のうち「岡山市東山公園」。岡山県立記 録資料館蔵。

注 47）山陽新報、大正 8 年 4 月 13 日。

（2010年 5 月26日原稿受理，2010年 9 月29日採用決定） 